UDC $330.43+519.862$

DOI: https://doi.org/10.32782/2413-9971/2020-29-16

\author{
Kozytskyi Valerii \\ PhD (Physics and Mathematics), Associate Professor, \\ Associate Professor at the Department \\ of Mathematical Economics and Econometrics \\ Ivan Franko National University of Lviv
}

Козицький В. А. кандидат фізико-математичних наук, доиент, дочент кафедри математичної економіки та економетріі Львівського національного університету імені Івана Франка

\title{
PRICE DYNAMICS MODELING: CHAOS MODEL APPLICATION
}

Summary. The article investigates the dynamics of price index that is described by nonlinear difference equations. The simulation model takes into account different initial positions of system as well as different parameters' values. The decision-making process depends on the values of exogenous factors that affect the system behavior and lead to stability or instability results. The simulation results revealed the bifurcation point and showed that the system can behave unpredictable and demonstrate chaos dynamics even with small change in initial conditions. If the initial value is greater than equilibrium point it has been obtained the attraction for the system. If the initial value is less than equilibrium point it has been obtained the repelling for the system. The price dynamics showed a saddle-node bifurcation that determined the equilibrium points of the system and exhibited the U-shaped curve.

Key words: chaos theory, nonlinear system, price index, dynamics, bifurcation, labor market.

Introduction. The chaos theory applies to wide range of economic problem associated with optimization issues where the dynamics of system is highly sensitive to change in initial condition and reveals the feature of randomness. R. Tang, S. Fong and N. Dey (2018) conducted ten chaotic approaches and developed the metaheuristic algorithms to achieve a goal to extend and explore the efficiency of chaos theory due to improvement of research capability. Scientists provided several extensive experiments and showed that chaotic optimization is powerful tool for evaluation of optimization algorithms [1]. M. Oliskevych and V. Tokarchuk (2018) revealed the distinctive regimes of the behavior of the unemployment rate over time, which is associated with declining and rising modes, by Markov switching autoregressive model [2].

Literature review. N. Wesner (2004) defined a new scientific approach for indicating of low dimensional chaos in small sample sets and leveraged it to investigation of financial data with few annual and monthly available observations [3]. Scientists provided the nonlinear econometric analysis of dynamic changes in main macroeconomic indicators of labor market functioning and revealed the asymmetric behaviour and the asymmetry in response to positive and negative macroeconomic shocks $[4 ; 5]$.

M. Akhmet, Z. Akhmetova and M. Fen (2014) explored the generation of chaos in economic environment caused by exogenous shocks. The fluctuations were described by the pulse function with chaotically behaved values. The application to Kaldor-Kalecki-type models of aggregate economy proved the existence of export and rainfall shocks and demonstrated the important consequences for the policy makers [6].

The chaos theory is also useful tool for investigation of labor market properties and impact of shocks on employment and labor force participation. T. Kamihigashi (2000) examined the wealth distribution dynamics in a small open economy and focused on discrete-choice problem with optimal policy function that determined the ergodic chaos. The research showed that the wealth distribution moved to unique distribution whereas the aggregate wealth converged to the invariant value [7]. The results, achieved by different numerical experiments, revealed the evidence that ergodic chaos exhibited the aggregate stability and did not follow instability in behavior. M. Oliskevych and I. Lukianenko emphasized the role of nonlinearities, structural changes and shock impact on socio-economic sphere and labor market [8;9].

Methods. Chaos does not require random nature. If there is something accidental, it cannot be predicted. On the other hand, the deterministic system is quite predictable. However, if the system depends on the initial conditions and moves quite differently for different initial conditions, even if they are very close, then the system becomes unpredictable.

Chaotic systems only occur when we have nonlinearities. Even very simple nonlinear deterministic systems can show chaos. Consider the nonlinear difference equation for labor force price:

$$
p(t+1)=\beta p(t)(1-p(t)) ; \quad 0 \leq \beta \leq 4 .
$$

This equation applies only to one variable $p$ that depends on time and the parameter $\beta$. To find the sequence of values for $p$ it needs to determine the initial state $p(0)$ and the value of $\beta$. No matter what the sequence looks like it will be always the same for the same initial condition and the same parameter value. Let time $\mathrm{t}$ changes from 0 to 20 . The equation for $p(1)$ is: $p(1)=\beta p(0)(1-p(0))$.

For $p(0)=0.5$ and $\beta=1.5$, the series tends to the steadystate value of 0.3333 . There is nothing chaotic about this series (Fig. 1). However, if the value of $\beta$ is set as 3.82, the resulting series is completely different from the previous one (Fig. 2). The series alternately reaches a maximum and a minimum by the 10th period, then decreases approximately in the 17 th period, and then the cycle starts again. Thus, although the system is deterministic, it is far from predictable when $\beta=3.82$. The system seems to be quite chaotic.

Therefore, we received that a simple nonlinear equation (1) can exhibit rather chaotic behavior. The reason of chaotic behavior lies in bifurcation. Consider the case where the price is described by following nonlinear equation with one variable and one parameter:

$$
p(t+1)=f(p(t))=1.5 p(t)(1-p(t))-\lambda .
$$

Bifurcation theory determined the points in a system at which the behavior of the system changes as the value of the parameter is changed. A fixed point of this system satisfies the condition 


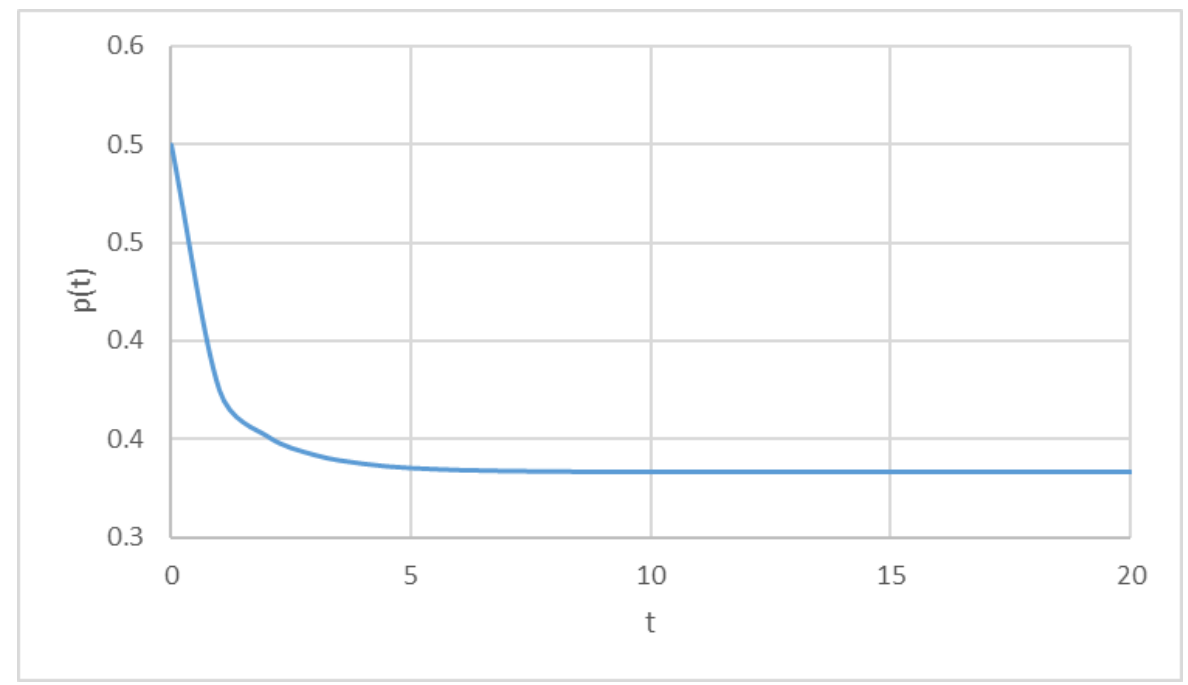

Figure 1. Dynamics of price index for $\beta=1.5$

Source: evaluation of the author

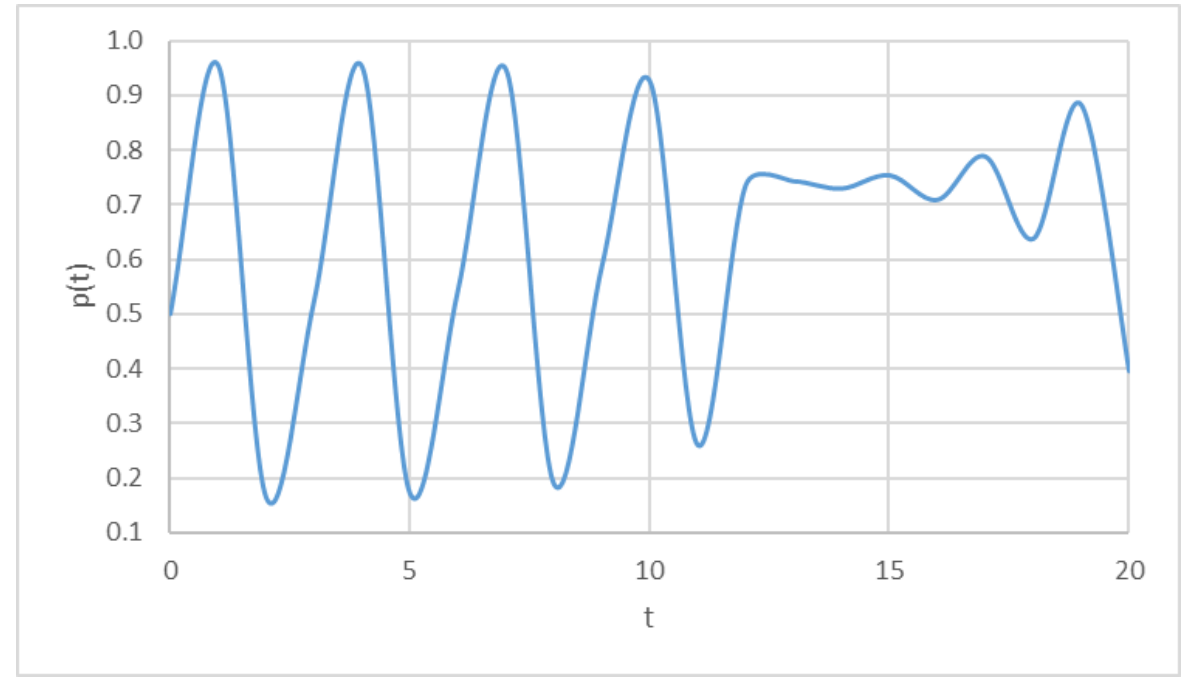

Source: evaluation of the author

Figure 2. Dynamics of price index for $\beta=\mathbf{3 . 8 2}$

$$
p^{*}=1.5 p^{*}\left(1-p^{*}\right)-\lambda
$$

that gives the equilibrium fixed point

$$
p^{*}=\frac{1 \pm \sqrt{1-24 \lambda}}{6}
$$

The equilibrium point $p^{*}$ depends on the exact value of $\lambda$. In addition, the stability properties of the equilibrium point also depend on the exact value of this parameter. For example, if $1-24$ $\lambda<0$, i.e. $\lambda>1 / 24$, then there is no equilibrium point. If $1-24 \lambda>$ 0 , i.e. $\lambda<1 / 24$, there are two equilibrium points: $p_{1}{ }^{*}$ and $p_{2}{ }^{*}$. If $\lambda=1 / 24$, the system characteristics change. On both sides of this magnitude, the characteristics of the system are quite varied.

Results. Stability is determined locally when there is more than one equilibrium point. Also, the fixed point stability is determined by the first derivative of function $f\left(\mathrm{p}=p^{*}\right)$ in (2). Of course, the equilibrium point depends on the value of $\lambda$. The first derivative is:

$$
f^{\prime}\left(p^{*}\right)=1.5-3 p^{*}
$$

Substitution of the equilibrium values given in (4) for the lower fixed point $p_{1}^{*}$ gives $f\left(p_{1}^{*}\right)=1.5-3 p_{1}^{*}=1.5-3 \frac{1-\sqrt{1-24 \lambda}}{6}=1+0.5 \sqrt{1-24 \lambda}>1$

for $\lambda<1 / 24$. Since the first derivative is positive at the equilibrium point $p_{1}{ }^{*}$, this equilibrium point is unstable or repelling.

Next, consider stability of point $p_{2}{ }^{*}$

$f^{\prime}\left(p_{2}{ }^{*}\right)=1.5-3 p_{2}{ }^{*}=1.5-3 \frac{1+\sqrt{1-24 \lambda}}{6}=1-0.5 \sqrt{1-24 \lambda}>1$,

for $\lambda<1 / 24$. However, that is correct only if $-1<f^{\prime}\left(p_{2}{ }^{*}\right)<1$, i.e.

or

$$
-1<1-0.5 \sqrt{1-24 \lambda}<1
$$

$$
-0.625<\lambda<0.0417 \text {. }
$$

This system is stable only for those values of $\lambda$ that is lying in the range $-0.625<\lambda<0.0417$.

The last case is when $\lambda=1 / 24=0.0417$. Now two fixed points have the same value, namely $1 / 6$. In addition, $f^{\prime}\left(p^{*}=1 / 6\right)=1$ and therefore the stability of a fixed point is inconclusive or semi-stable. The value $p^{*}=1 / 6$ is a bifurcation value for this problem. 


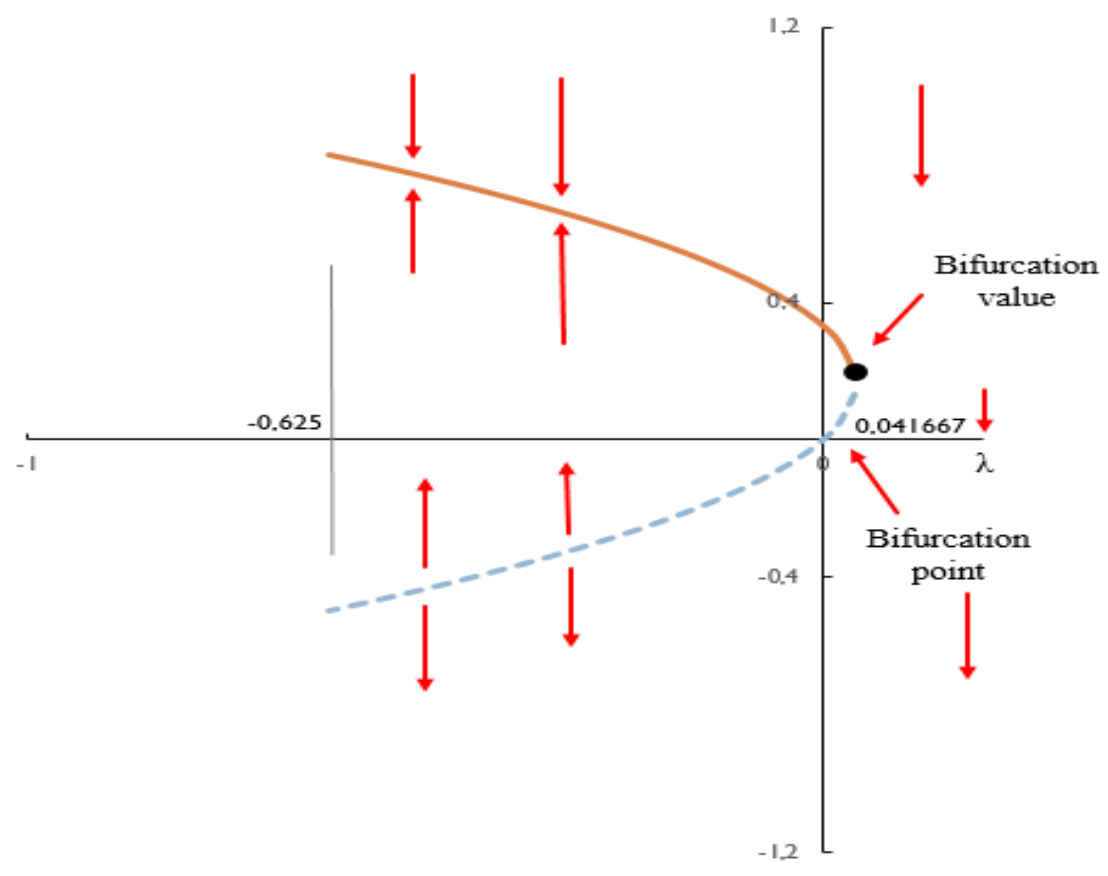

Figure 3. Bifurcation diagram

Source: Evaluation of the author
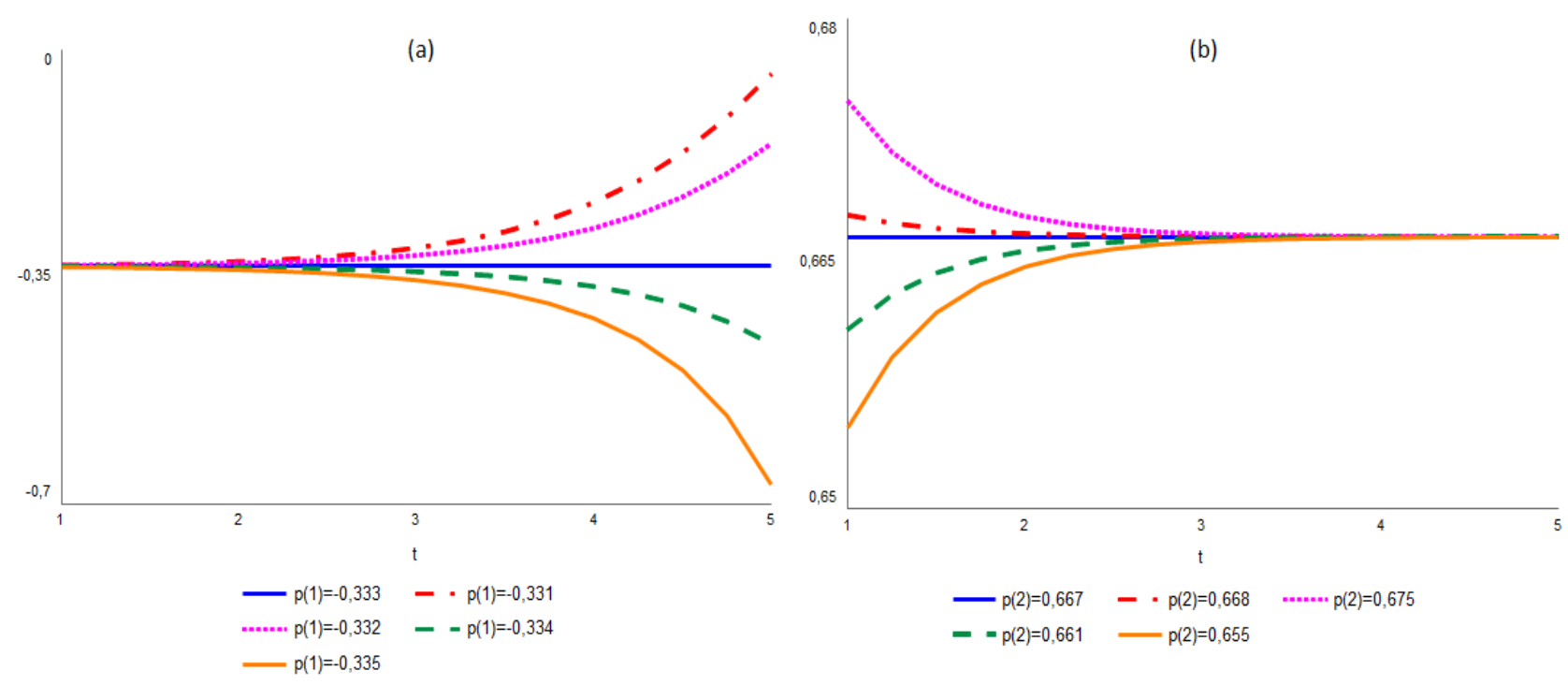

Figure 4. The dynamics of price defined by the equation (2) for $\lambda=-1 / 3$

Source: evaluation of the author

All cases are combined on the diagram that has the parameter $\lambda$ on the horizontal axis and the equilibrium point $\mathrm{p}^{*}$ on the vertical axis. Figure 3 demonstrates the bifurcation diagram.

Vertical arrows show the properties of equilibrium stability. At the bottom of the curved area, the arrows point upwards when they extend beyond the area. If $-0.625<\lambda<0.0417$, there are two equilibrium points, the greater one of which is stable and the lower one is unstable.

Value $N_{A}$ defines the number of equilibrium values of the system that depends on parameter $\lambda$. If, for any interval $\left(\lambda_{0}-\varepsilon, \lambda_{0}+\varepsilon\right) N_{A}$ is not a constant, $\lambda_{0}$ is called bifurcation point, and the system is said to undergo bifurcation when $\lambda$ passes through $\lambda_{0}$. For the system that is discussed we received:

$N_{A}=\{2$ for $\lambda<1 / 24 ; \quad 2$ for $\lambda=1 / 24 ; \quad 0$ for $\lambda>1 / 24\}$ (6) and so $\lambda=1 / 24$ is bifurcation.

The research shows the dynamics of system for different lambda. If $\lambda=-1 / 3$ the first point is unstable as it is shown in Figure $4 a$. The second point (Figure $4 b$ ) is stable.

The dynamics of system for $\lambda=1 / 24$ is given in Figure 5. It appears to be a bifurcation point. If the initial value is greater than this point, then we see attraction for the system. If the initial value is less than this point then we see repelling for the system.

Conclusions. The types of bifurcations is associated with the type of graph that they show such as saddle-node bifurcation or pitchfork bifurcation. For the price dynamics we obtain a saddle-node bifurcation that is determined so because at $\lambda_{0}$ the fixed points of the system exhibited a U-shaped curve, that is open at one end. 


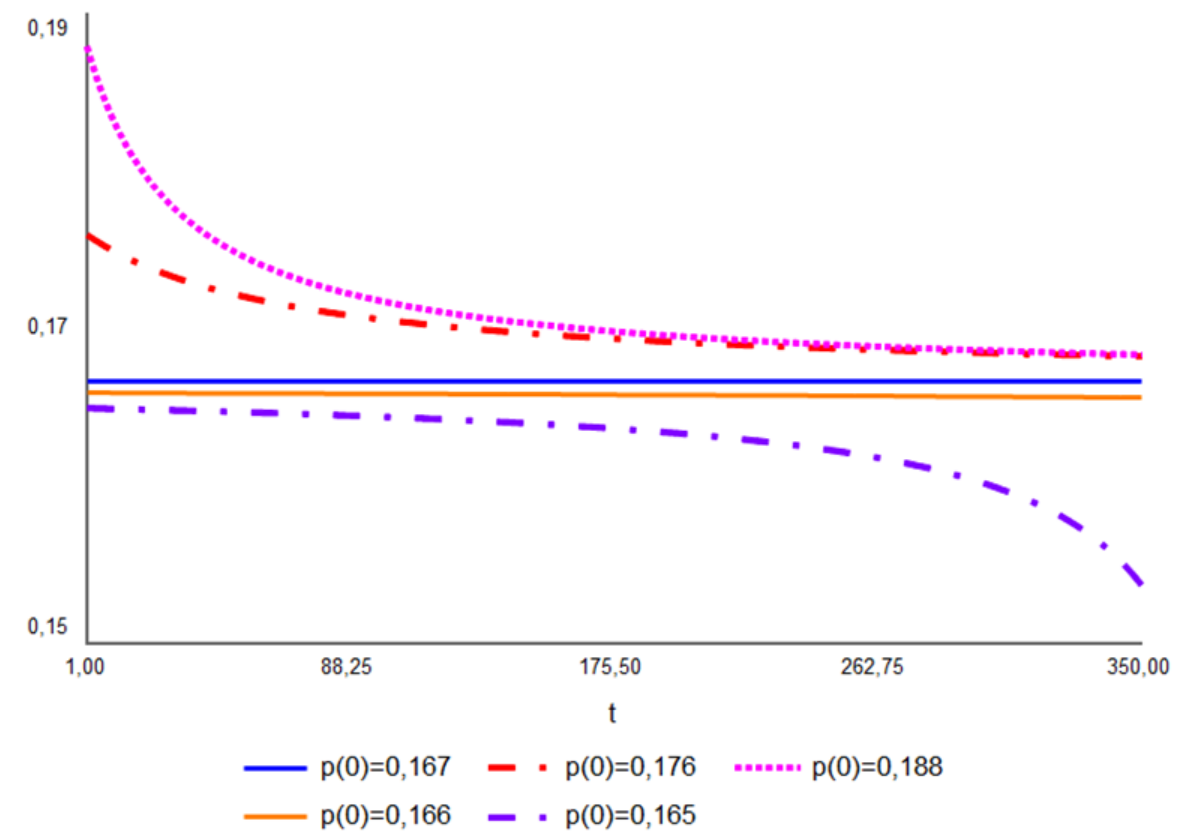

Figure 5. The dynamics of price defined by the equation (2) for $\lambda=1 / 24$

Source: evaluation of the author

\section{References:}

1. Tang, R., Fong, S. and Dey, N. (2018). Metaheuristics and Chaos Theory. Chapters, in: Kais A. M. Al Naimee (ed.), Chaos Theory, IntechOpen.

2. Oliskevych, M. and Tokarchuk, V. (2018). Dynamic Modelling of Nonlinearities in the Behaviour of Labour Market Indicators in Ukraine and Poland. Economic Annals - XXI, Vol. 169, Issue 1-2, pp. 35-39.

3. Wesner, N. (2004). Searching for Chaos on Low Frequency. Economics Bulletin, Access Econ, Vol. 3(1), pp. 1-8.

4. Oliskevych, M. and Lukianenko, I. (2019). Labor Force Participation in Eastern European Countries: Nonlinear Modeling. Journal of Economic Studies, Vol. 46 No. 6, pp. 1258-1279.

5. Oliskevych, M. (2015). Processes Dynamics Asymmetry at Labour Market: Nonlinear econometric Analysis. Actual Problems in Economics. N 2(164), pp. 427-436.

6. Akhmet, M., Akhmetova, Z. and Fen, M. (2014). Chaos in Economic Models with Exogenous Shocks. Journal of Economic Behavior \& Organization, Elsevier, Vol. 106(C), pp. 95-108.

7. Kamihigashi, T. (2000). Indivisible Labor Implies Chaos. Economic Theory, Springer; Society for the Advancement of Economic Theory (SAET), Vol. 15(3), pp. 585-598.

8. Oliskevych, M. and Lukianenko, I. (2017). Structural Change and Labor Market Integration: Evidence from Ukraine. International Journal of Economics and Financial Issues, Vol. 7(3), pp. 501-509.

9. Lukyanenko, I. and Oliskevych, M. (2014). Labour Market in Ukraine: an Empirical Dynamic Analysis Using Error Correction Model. Bulletin of Taras Shevchenko National University of Kyiv. Economics, Vol. 6(159), pp. 52-58.

\section{МОДЕЛЮВАННЯ ЦІНОВОЇ ДИНАМІКИ: ЗАСТОСУВАННЯ МОДЕЛЕЙ ХАОСУ}

Анотація. Теорія хаосу застосовується до широкого кола економічних проблем, пов'язаних з питаннями оптимізації, коли динаміка системи є дуже чутливою до зміни ії початкового стану та виявляє динамічні особливості подібні до випадкових коливань. Моделі хаотичної динаміки не вимагають включення випадкової складової, поведінку якої не неможливо передбачити, тому дають змогу описати динаміку цін за допомогою детермінованого процесу, що можна прогнозувати. У статті досліджено динаміку індексів цін за допомогою нелінійних різницевих рівнянь. Імітаційна модель враховує різні початкові положення системи, а також різні значення ії параметрів. Показано, що динаміка системи цін суттєво залежить від початкових економічних умов і демонструє зовсім різну якісну поведінку навіть за дуже близьких початкових значень. Результати моделювання засвідчили наявність точок біфуркації та показали, що система цін в економіці може вести себе непередбачуваною та демонструвати динаміку хаосу навіть за невеликих змін у функціонуванні економіки. Процес прийняття рішень залежить від значень екзогенних факторів, які впливають на поведінку системи та призводять до стабільності або нестабільності. У статті побудовано нелінійну модель динаміки цін, що виявляє хаотичну поведінку. Показано, що причина візуальної випадковості обумовлена наявністю точок біфуркації. Всі випадки динаміки описано діаграмою, що відображає напрям поведінки системи цін залежно від параметра коригування, визначеного на горизонтальній осі, та точки рівноваги, значення якої відображено на вертикальній осі. Стрілки обгрунтовують властивості стійкості, притягання до рівноваги чи навпаки відштовхування від неї. Якщо початкове значення перевищує рівноважне значення ціни, то отримано притягальні цикли поведінки, атрактори. Якщо початкове значення менше за рівноважне значення ціни, отримано відштовхувальні граничні цикли. Тип біфуркацій визначається типом графіка, який вони характеризують. У результаті дослідження динаміки цінових індексів отримано точки біфуркації, які визначають розгалуження динаміки типу сідлового вузла, визначено стійкі точки рівноваги системи та обгрунтовано U-подібну криву, відкриту на одному кінці. Розроблена модель дає змогу проводити аналіз можливих альтернативних сценаріїв і прогнозувати динаміку цін за різної монетарної політики.

Ключові слова: теорія хаосу, нелінійні системи, індекс цін, біфуркація, ринок праці. 


\section{МОДЕЛИРОВАНИЕ ЦЕНОВОЙ ДИНАМИКИ: ПРИМЕНЕНИЕ МОДЕЛЕЙ ХАОСА}

Аннотация. В статье исследуется динамика индекса цен, описываемого нелинейными разностными уравнениями. Имитационная модель учитывает различные начальные положения системы, а также различные значения параметров. Процесс принятия решений зависит от значений внешних факторов, которые влияют на поведение системы и приводят к стабильности или нестабильности. Результаты моделирования выявили точку бифуркации и показали, что система может вести себя непредсказуемо и демонстрировать динамику хаоса даже при небольшом изменении начальных условий. Если начальное значение больше точки равновесия было получено притяжение для системы. Если начальное значение меньше точки равновесия было получено отталкивание для системы. Динамика цен показала раздвоение седлового узла, которое установило точки равновесия системы и определило U-образную кривую.

Ключевые слова: теория хаоса, нелинейная система, индекс цен, динамика, бифуркация, рынок труда. 